sympathizers to obtain the necessary further particulars from the address above. The last date for the posting of the essays is May 1, 1937, so that ample time is allowed for all inquiries and for the writing of so short a composition. It will not be the length, however, but the pregnancy of what is said that will arouse attention, and one hopes most sincerely that something may be said which will bring light and hope to this most perplexing and dangerous question. Everyone knows, and most people admit, for example, that Great Britain in this matter of rearmament is acting most unwillingly and feels herself compelled to her present action by what is being done by others. If this is to go on, the vicious circle is complete. How to break it? That is the question to which the essayists will have to address themselves.

IT is not for us here to sketch an essay for the competition, but it does seem possibie that after our darkest moment light may appear. The appalling business which now absorbs our attention in Spain may prove the turning point for an upward move. ment of peace. It is clearly seen that this conflict is a reflection, in a distorted form, of the greatest underlying conflict which is threatening the peace all over the world, that between what is called 'fascism' or an authoritarian and comprehensive nationality, and 'communism' or the organized power of the manual workers. Men see now the hideous excesses and dangers of extinction which threaten civilization, if such a conflict is pushed to extremes. They must see also that, as in England, there is no essential reason why the conflict should not be avoided by rational compromise and good. will. There is an honest and widespread movement on foot to avoid extreme courses in the case of Spain. Clearly something must be done there, to save that country from extinction. This may be the lesson which the worId so badly needs. It is at least plainly written in the events of the last three months. The friends of science will also reflect that the crisis has occurred in the one land in Western Europe where science had taken least root, the one place where there was no renascence of science in the seventeenth century. That was the proper scene for the play of the forces of unreason. No other Western land has been torn by such an internecine strife; no other was so unfortunately free from the pacifying influences of scientific education.

\section{Spawning of the Common Toad}

IT is only during recent years that biologists have realized that they are far from a complete understanding of the influence of external factors on the spawning of even the commoner amphibians. The common toad (Bufo bufo bufo) is an 'explosive breeder', that is to say, all the sexually mature individuais in a district migrate from their diverse hibernation quarters to their breeding sites within a few days of one another, and within even large areas there is singularly little deviation from the normal of the year. There have been occasional records of isolated pairs found spawning long after the normal time, but sorne observations made by Mr. G. Shrub. sole, who writes from the Victoria Court Hotel, Eastbourne, made during the last two years, seem to indicate the existence in Sussex of an area which is exceptional. A series of small ponds on Beachy Head were visited at intervals for conchological work, and on July 30 and August 1, 1935, unhatched toad spawn was found in at least three of them. One pond was kept under observation and unmetamorphosed tadpoles were still found at the beginning of December. In 1936 tadpoles were first found in the same, and one other pond, at the beginning of May, but never throughout the year were they ever observed in any of the others. The development of the tadpoles was apparently very slow, for even in September the majority still had mere rudiments of hind-limbs. But whether these very late tadpoles were of the same brood as those found early in May is uncertain (the normal larval period is only 12-14 weeks), for although no fresh spawn was found, adult toads were discovered in the water in July. Their presence at a time so long after tadpoles had been observed is unusual, for the whole of the breeding operations are normally concluded within a week or so, and the adults then leave the water for the rest of the year. Their presence certainly suggests the possibility that there may have been a July spawning in 1936, as there was in 1935, and, if this proves to be a regular occurrence, a detailed investigation of the physical conditions of the district should be of importance.

\section{Native Labour from Nyasaland}

Tre announcement by the Colonial Office that the Governments of Southern Rhodesia, Northern Rhodesia and Nyasaland have entered into a provisional agreement regulating the employment of emigrant labour from the last-named has come shortly after Mr. Ormsby-Core's recent insistence on the importance of the labour problem in its effect on the well-being of the native community (see Narure, Oct. 31, p. 735). It is an assurance that the conditions to which the report of the Committee on emigrant labour from Nyasaland has directed attention will not be allowed to continue without a serious en. deavour to eliminate those factors which have been shown to be the cause of hardship and suffering, as well as a danger to the future prosperity of the Protectorate. The agreement is to remain in force for four years as from August 21 last, and thereafter is terminable at twelve months notice. Under its terms, identification certificates are to be issued to all male natives seeking employment, and those leaving their own territories for that purpose will bear evidence to that effect, as well as a notification of physical fitness. In future, so far as native and industrial conditions permit, only such certificated labour will be admitted by the employing Governments. Not only will the flow of labour be controlled, if necessary, but also-a matter of much greater importance-labourers are to be returned to their own territory after an economic period of employ. ment, which is not to exceed two years. This 
provision, even if it does not entirely remove the evil of a permanent loss in population, will at least lessen the numbers of those who do not return to their homes after a period of extra-territorial employment. A further important provision sets up a standing committee of representatives of the three Governments to secure co-ordination and to consider problems in connexion with the supply of labour as they arise.

\section{Population Investigation Committee}

IT is announced in The Times of November 5 that a committee has been formed to investigate the fall in the birth-rate in Great Britain and its probable consequences. The committee, which has been appointed by the council of the Eugenics Society, is presided over by Prof. A. M. Carr-Saunders, and has among its members, Lord Horder, Mrs. Hubback, Dr. Julian Huxley, Prof. L. Hogben, Dr. R. R. Kuczynski, Lady (Rhys) Williams, Prof.J. Young, and other authorities on various aspects of the subject. Dr. C. P. Blacker, the general secretary of the Eugenics Society, is honorary secretary of the Committee, and Mr. D. V. Glass is research secretary. $\mathrm{Mr}$. Glass has recently published a useful book on this subject, entitled "The Struggle for Population". The committee has already held two meetings, and its investigations are gradually taking shape. The main object is, in the first place, to ascertain the facts of the case and the causes of the decline in the number of births per family; and for this purpose it invites the co-operation of institutions and individuals engaged upon relevant lines of research. Inquiries may be addressed to the Secretary, Population Investigation Committee, 69 Eccleston Square, London, S.W.l.

\section{New Discharge Bulb Lamps}

THE new discharge bulb lamps are already in use on the Continent, and judging from the fact that they were shown at a meeting of the Illuminating Engineering Society on October 13, they will probably be soon on sale in Great Britain. In appearance, they are like the ordinary 'pearl' lamp but they have no filament. They contain a small quartz mercury vapour discharge lamp "about the size of half a cigarette" and they are corrected for colour. Internally the bulb is coated with a fluorescent powder, in the same way as the lower area of the inside of the cathode ray tube, where the picture is shown in television reception. According to the Electrical Contractor of November, the lamps are available in two sizes, 80 watts and 125 watts. The light output of these lamps is about 40 lumens per watt. This compares with the 12 lumens per watt of the ordinary coiled-coil incandescent lamp. The life is stated to be about 1,500 hours. The 'colour correction' of these lamps is effected by the fluorescent powder used. The human complexion when illuminated by the lamps shown at the meeting was very little altered, the change being scarcely noticeable. Owing to the fact that the internal film transforms the invisible ultra-violet light emitted by the mercury vapour lamp into light of visible wave-length, the loss of light by the absorption of the bulb is compensated for by this fluorescence. No details are yet available as to the price of the lamp, but we seem to be on the eve of a new development in house lighting.

\section{Recent Acquisitions at the Science Museum}

THE Oxford heliometer of 1848 has been placed on exhibition in the Astronomy Collection (Gallery LXIV). This instrument was made for the Radcliffe Observatory, Oxford, by Messrs. A. and G. Repsold of Hamburg on the advice of the famous German astronomer F. W. Bessel, who had in 1838 with a similar instrument obtained the first satisfactory measure of the parallax of a fixed star. The distance of the star, 61 Cygni, was found to be some 400,000 times the sun's distance of $93,000,000$ miles. The Oxford heliometer was for many years one of the most powerful and accurate instruments of its kind in the world. It is notable among other things for the first application of electrical illumination to an astronomical instrument. It was dismounted and taken to pieces in 1906, and so remained until its removal in 1935 to the Science Museum, where it has been renovated and set up as it was originally, a striking testimony to the nineteenth century instrument maker's art. In the Chemistry Collection (Gallery LXVI), an original tube of the metal rhodium prepared by its discoverer, Dr. William Hyde Wollaston, about 1825 has been placed on exhibition. Rhodium has recently become of interest as a nontarnishing substitute for silver in electroplating.

\section{Zoological Survey of India}

THE report of the Zoological Survey of India, recently issued, covers the years 1932-35, coinciding with a period of retrenchment in civil expenditure and consequent restriction of activities. It records the retirement of Lieut.-Colonel R. B. Seymour Sewell in 1933, and his subsequent extensive biological investigations as leader of the Murray Oceanographical Expedition to the Indian Ocean, and is written by his successor, Dr. Baini Prashad. The investigations of the Survey include detailed work upon the Trochus shell fisheries of the Andaman Islands; identification of animals of economic importance from the medical or sanitary point of view, carried out for various institutions and public bodies ; identification of human and animal remains excavated at various chalcolithic sites in Sind; and anthropological work connected with the census. Unfortunately, the abolition of the post of zoological collector and the necessity of restricting expenditure has greatly reduced the field-collecting and observations which used to be so desirable and characteristic an activity of the Survey.

\section{Bibliography of Seismology}

The last two quarterly numbers of the "Bibliography of Seismology" prepared by Mr. E. A. Hodgson and printed in the Publications of the Dominion Observatory, Ottawa (12, 159, 181 ; 